\title{
2.1. El Found Footage como práctica del video-arte argentino de la última década
}

\section{Vallazza, Eleonora [ver currículum del autor, docente de la Facultad de Diseño y Comunicación]}

\section{Abstract del proyecto:}

El presente trabajo tiene como objetivo resultar relevante para las carreras de Comunicación Audiovisual y Dirección Cinematográfica en particular, pero también puede resultar de interés para otras carreras vinculadas a la comunicación audiovisual como ser Diseño de Imagen y Sonido y Fotografía, que se dictan en la Facultad de Diseño y Comunicación. Por lo tanto el área a la que responde es la Audiovisual. Este trabajo será de utilidad para el alumnado de las carreras anteriormente citadas, ya que plantea el análisis de una tendencia en crecimiento dentro del campo audiovisual en general y del video arte en particular. Si bien, los primeros realizadores de la práctica Found Footage pertenecen a la cinematografía mundial, en Argentina durante la última década se ha desarrollado ampliamente. El resultado de dicha exploración será de gran utilidad como material de consulta para los alumnos interesados en vincularse tanto desde la investigación como desde la práctica, con esta tendencia en crecimiento. La práctica del Found Footage o cine encontrado, es nombrada también por las lenguas latinas como "película de montaje". Este concepto incluye un conjunto de películas muy variadas que están basadas en un material preexistente ya sea de archivo u otra procedencia y son reutilizadas para generar un nuevo discurso. Por lo tanto se generan nuevas obras a partir de obras preexistentes. El desarrollo de dicha tendencia se materializa en la presencia en festivales internacionales como ser el BAFICI (Buenos Aires Festival Internacional de Cine Independiente) en el que participan realizadores argentinos.

Dicha investigación será realizada por mi persona, sin la participación de alumnos u otros docentes. Sin embargo será imprescindible realizar entrevistas a realizadores, críticos y teóricos del medio especializados en el tema, ya que no existe una bibliografía amplia debido a lo incipiente y experimental que resulta ser el objeto de estudio.

Trabajaré con bibliografía específica, complementaria y sitios Web dedicados al tema. Las teorías con las que el presente proyecto se vincula, desde el campo específico son aquellas que definen y estudian lo experimental y las nuevas tendencias surgidas desde los tiempos de la posmodernidad. También con teorías provenientes de la filosofía y puntualmente de la estética que estudia el concepto de creación artística y creatividad, como con 
teorías provenientes de la sociología de la cultura como ser los conceptos de campo intelectual y proyecto creador.

\section{Palabras clave:}

audiovisual - cine - montaje

Encuadre académico

La información brindada por la presente investigación, es relevante para las carreras vinculadas al diseño audiovisual, o sea, se constituye en una fuente de consulta y referente para las carreras del área Audiovisual que se dictan en la Facultad de Diseño y Comunicación de la Universidad de Palermo: Comunicación Audiovisual, Dirección Cinematográ- fica, Dirección de Arte de Cine y TV, Guión de Cine y TV, Dirección de Actores de Cine y TV, y Fotografía. Si bien éstas son las carreras a las que atañe particularmente por ser la exploración de una tendencia en crecimiento dentro del campo audiovisual argentino, también resulta de interés para estudiantes de carreras vinculadas al estudio y diseño de la imagen en su más amplia variedad. Por lo tanto otras carreras que pueden considerar relevante dicha investigación son: Publicidad, Creatividad Publicitaria y Dirección de Arte Publicitario, que pertenecen al área académica Comunicación y Creatividad Publicitaria, como también para las carreras Diseño Gráfico perteneciente al área de Diseño Visual y Diseño de Imagen y Sonido del área Multimedia.

En relación a la formación de los profesionales del sector audiovisual en particular, y del resto de las carreras relacionadas con el estudio y la creación de imágenes, la presente investigación influye en un sentido doble. Por un lado, la temática propuesta ofrece una recopilación de contenidos y desglosa una serie de creadores audiovisuales pocas veces incluidos en las planificaciones académicas de las carreras nombradas. Es así como resulta importante como fuente de consulta, y como material de estudio para aquellos profesionales que quieran vincularse a esta práctica experimental de la creación audiovisual. Promoviendo de alguna manera, una ampliación en el campo de desarrollo profesional y creativo, más relacionado con el campo de la plástica. Por otro lado, como será desarrollado a continuación, la práctica del Found Footage implica una postura crítica y reflexiva frente al propio medio. Es así como el alumno que se enfrente al estudio de dicha práctica creativa tendrá la posibilidad de incorporar una mirada crítica, reflexiva y por sobre todo deconstructiva de la obra audiovisual, que podrá extender al resto de las áreas de su desarrollo profesional.

\section{Fundamentación}

El resultado de la presente investigación tiene como meta ser de utilidad para el alumnado de carreras vinculadas con el universo audiovisual: Licenciatura en Comunicación Audiovisual, Dirección Cinematográfica, Diseño de Imagen y Sonido en particular pero también tiene por objetivo ser material de consulta y fuente de referencia en carreras vinculadas a la imagen y al diseño en general.

El objeto de estudio, que será detallado a continuación, es lo suficientemente complejo como para poder ser abordado desde diferentes miradas teóricas: estética, filosófica, social y antropológica en una visión más amplia de la cuestión, como por diferentes teorías desarrolladas para el estudio de la imagen y de la imagen audiovisual en particular.

Por otro lado, es un tema de estudio que no ha recibido la suficiente teorización o investigaciones académicas legitimadas, que permitan incorporarlo al currículum ni planes de estudio de las carreras anteriormente mencionadas. Existe el estudio de la tendencia Found Footage en el marco de la educación no formal a modo de seminario o talleres extracurriculares, pero apenas es considerada en la planificación de los programas de las carreras de comunicación y diseño. 
Si bien, los primeros realizadores de la práctica Found Footage pertenecen a la cinematografía mundial, en Argentina durante la última década se ha desarrollado ampliamente. Por lo tanto, el resultado de dicha exploración será de gran utilidad como material de consulta para los alumnos interesados en vincularse tanto desde la investigación como desde la práctica, con una tendencia en crecimiento.

Como será detallado a continuación, la práctica del Found Footage implica una crítica frente al medio cine o video (de acuerdo al soporte), por lo tanto la ejercitación por parte de los alumnos de dicha práctica implicará un conocimiento crítico y reflexivo sobre el medio y sobre el concepto de la creación artística que replantea supuestos filosóficos instalados en la cultura y educación occidental. Es así que tanto el análisis como la práctica de dicha tendencia, permitirá a los alumnos no sólo acercarse a la incorporación de nuevos conocimientos sino también a ejercitar un conocimiento crítico y reflexivo sobre el medio estudiado y analizado por otras disciplinas a lo largo de su formación profesional.

\section{Tipología}

El presente Proyecto de Exploración de la Agenda Profesional trata sobre el estudio de una tendencia dentro del campo de la producción audiovisual contemporánea. Esta tendencia, no es propia de este siglo, sin embargo el desarrollo vertiginoso y exhaustivo de las nuevas tecnologías, permite que el crecimiento y los alcances de dicha tendencia, sean mucho más fuertes y abarcativos desde la última década al día de hoy.

\section{Necesidad que cubre}

La necesidad básica que cubre es la de generar un nuevo ámbito de investigación dentro del campo del universo audiovisual como también la de cubrir la falencia sobre fuentes y materiales de consulta para alumnos como para interesados en el medio audiovisual en general. Si bien el tema, tiene antecedentes en publicaciones especializadas de cine el ámbito de circulación y recepción de dichas publicaciones se encuentra restringido a: publicaciones especializadas, libros de estudio de teoría e historia de cine, o publicaciones editadas por festivales de cine internacionales. Más allá de facilitar el acceso a un tipo de información, que circula en ámbitos muy cerrados y específicos, los resultados de dicha exploración generarán la necesidad de revisar, modificar y ampliar los contenidos de las planificaciones curriculares de las carreras anteriormente mencionadas. Por lo tanto no solamente será de gran utilidad para los alumnos interesados en el objeto de estudio, sino que también ayudará a replantear los contenidos que forman parte de las asignaturas de las carreras en cuestión, colaborando con la necesaria actualización y reformulación de los contenidos que conforman los currículums de la enseñanza superior en diseño y comunicación.

\section{Descripción}

A modo introductorio, se puede definir a la práctica del Found Footage o cine encontrado, que es nombrada también por las lenguas latinas como película de montaje. Son films que se realizan a partir de la presencia de un material preexistente, por lo tanto se generan nuevas obras a partir de obras preexistentes. Este material se caracteriza por incluir un conjunto de películas muy variadas procedentes, ya sea de archivo u otras fuentes (mercados de pulgas, cestos, material descartado por distribuidoras, etc.) que son reutilizadas para generar un nuevo discurso. En la mayoría de los casos, el resultado de esta nueva obra suele generar un discurso bastante distinto a lo que pretendían los materiales originarios. Los géneros que incluyen también son muy amplios desde noticieros, films educativos, institucionales, propagandísticos, pornográficos, amateurs, familiares y etnográficos. Esta variedad también se da en los soportes de los mismos desde $8 \mathrm{~mm}$, Súper $8,16 \mathrm{~mm}$, video, etc. El desarrollo de dicha tendencia se materializa en la presencia en festivales internacionales como ser el BAFICI (Buenos Aires Festival Internacional de Cine Independiente) en el que participan realizadores argentinos.

Es un cine definido por un tipo de práctica, que en general es una práctica crítica. Es así como se lo relaciona de manera directa con las prácticas de los artistas dadaístas desde el collage hasta los ready made. Para ubicarlo en un momento de la historia se puede afirmar que esta práctica se da de manera consciente por primera vez con el realizador experimental Bruce Conner y su A movie by Bruce Conner de 1958. Este camino iniciado por 
Bruce Conner, continuó desarrollándose ampliamente desde fines de los '60 con realizadores como Gustav Deutsch, Jonas Mekas, David Rimmer, Yervant Gianikain y Angela Ricci Lucci, Craig Baldwin, Ken Jacobs entre otros, y por Latinoamérica los nombres más reconocidos son los de Camilo Botero Jaramillo, Gustavo Galuppo, Pablo Marin y Eugeni Bonet, entre otros. Uno de los ralizadores, que dentro del universo Found Footage, es considerado un referente artístico fundamental es el realizador austríaco Peter Tscherkassky. Los estilos y tendencias que se dan dentro de la práctica mencionada, son muy amplios y eclécticos, por lo tanto se procederá al análisis pormenorizado de casos, para poder afirmar ciertas conclusiones sobre las características más sobresalientes de dicha tendencia, haciendo hincapié en casos argentinos y contemporáneos.

En términos generales se puede afirmar que las diferentes tendencias dadas dentro de este tipo de práctica audiovisual, están marcadas básicamente por el soporte material de las películas encontradas. Por lo tanto es posible hablar de una tendencia materista, cuyo objetivo está dado por la manipulación del material fílmico, el celuloide expuesto en su máxima expresión a partir de su manipulación que en ocasiones llega a su destrucción. El realizador Eugeni Bonet denomina "cine métrico" a la tendencia del cine experimental que encuentra desarrollo en el found footage más destructivo, interviene el material original para que ostente su calidad de superficie, de objeto, exponiendo así la trama fílmica. El found footage experimental tiene como su principal referente a Peter Tscherkassky, y algunas de sus obras más recientes son Happy-End (1996), L'Arrivée (1997/98), Outer Space (1999), Get Ready (1999), Dream Work (2001) e Instructions for a Light and Sound Machine (2005). Un caso extremo y contemporáneo que responde a esta línea materista es el de la obra Wound Footage (2003-2009) del director alemán Thorsten Fleisch. Esta obra consiste en la manipulación de un rollo Super 8 con el fin de exponer las distintas etapas de la distorsión del material original. El espectador es enfrentado a un proceso de desintegración y transformación que va desde la quemadura del celuloide al mosaico de píxeles. De alguna manera, la obra simboliza el camino de lo analógico a lo digital desde la transformación de la materia y esto lo logra por el procedimiento creativo dividido en las siguientes etapas: en un primer momento registra la descomposición del celuloide con una cámara de video, luego la baja a la computadora y la vuelve a filmar desde el monitor, convirtiendo así lo analógico en digital.

Por otro lado, otra tendencia con gran desarrollo es el que Bonet denomina compilation film o película collage que usa técnicas de montaje o desmontaje para alterar corregir o analizar la película encontrada y este tipo de práctica incluye tanto películas en soporte fílmico como en video analógico y digital. Estas películas collage corresponden a una intencionalidad artística más conceptual que muchas veces se transforma en un vehículo para expresar la mirada política de los realizadores sobre alguna temática en particular.

La obra Elvira en el Río Loro (2009) del realizador argentino José Villafañe puede encuadrarse dentro de esta tendencia. A partir de un material encontrado que incluye imágenes de programas de televisión de la década del '70, como fragmentos de films familiares, el director decidió realizar un relato a partir de una voz en off que va narrando las diferentes etapas de una historia ficcionalizada. En este caso se trabaja con el tema de la reconstrucción de un pasado traumático y doloroso, como el de la última dictadura militar en Argentina, a partir de la narración de una historia íntima creada por el director a partir de las imágenes encontradas.

El realizador argentino Gustavo Galuppo, trabaja con video y se encuentra más vinculado al mundo del video arte, dentro de sus obras más recientes se encuentran: Yo, Duras (2010), Fedra o la desesperación (corto 2008), Sweetheart - Storie(s) About Accidents of Love (2006) y Días enteros bajo las piedras (2004). La peculiaridad de la obra Yo, Duras (2010) esta en que a diferencia de otros exponentes del Found Footage 
consiste en un largometraje. El punto de partida de dicha obra es la obra cinematográfica y literaria de Margarite Duras, relacionando parte de su obra con otras películas hasta inclusive registros propios. Estos materiales heterogéneos están vinculados a través de un montaje y un discurso definido por una mirada sobre la obra de Margarite Duras. Gustavo Galuppo materializa a través del montaje de estos elementos heterogéneos, un tipo de discurso teórico sobre el cine fundado históricamente por André Bazin, que analiza y estudia a la técnica del montaje homologándola con la experiencia de la escritura literaria.

Otro largometraje argentino y contemporáneo es Teoría de Cuerdas (2011) y fue realizado bajo la dirección colectiva de Luján Montes, Gabriel González Carreño, Clara Frías, Laura Focarazzo, Oscar Maio, Luciana Foglio, Eugenia De Rossi, Sergio Brauer, Juan Tancredi, Antonio González Mediondo y Amado Casal. Esta experiencia colectiva, fue presentada en el marco del BAFICI $13^{\circ}$ (Buenos Aires Festival Internacional de Cine Independiente) en la sección competitiva de Cine del Futuro. Cada segmento de este film tiene el título de algún elemento químico, las imágenes que presenta son de las más diversas fuentes: archivo documental, videos caseros, etc. Las mismas son presentadas a modo de collage, de fusión y combinaciones que abarcan distintas prácticas del cine experimental: found footage propiamente dicho, el remix digital y la estética documental reconstruida por la abstracción de la imagen. El film avanza a partir del ritmo musical generado por la edición de las diferentes imágenes presentadas en el film, rompiendo con la cuestión del relato o de la mirada de los directores sobre una determinada realidad.

Más allá de la intervención del material encontrado, existe también una tendencia dentro de la práctica Found Footage en la que los realizadores no generan ningún tipo de manipulación o intervención en términos de montaje y edición sobre dicho material. Algunos directores sostienen que proyectaron los films tal cual los encontraron, sin realizar ninguna intervención sobre los mismos. Sin embargo en estos casos también se produce un cambio interpretativo, ya que el contexto cambia, la finalidad también y por consiguiente los efectos que produce en el espectador. Ejemplos concretos de este caso son las obras Tearoom (1967/2002) de William E. Jones y March 14,1938 (2008) de Christoph Weidrich. Ambos aseguran no haberlas intervenido, Tearoom es una cinta familiar encontrada en el departamento de investigaciones de la policía de Ohio y March 14,1938, una película casera, obtenida en un mercado de pulgas austríaco, que muestra escenas cotidianas de una familia en un día cualquiera, ese día cualquiera resulta ser el 14 de marzo de 1938, el mismo en que Austria es asediada y ocupada por las fuerzas nazis.

En relación a esta última tendencia se encuentran las denominadas películas huérfanas. Paula Félix-Diddier (Directora del Museo del Cine de la Ciudad de Bs. As.) lo desarrolla en su capítulo del libro editado por BAFICl Cine encontrado: ¿Qué es y adónde va el found footage? (2010). Es un metraje encontrado que proviene de espacios ajenos al archivo institucional. En los '90 se desarrolló el término huérfanos para aquellos films que por diversas razones quedan fuera de los programas de rescate y restauración, cumpliendo así con la preservación de la memoria audiovisual no oficial. En Estados Unidos, existe el festival Orphans dedicado a estas películas, en el que diferentes personas e instituciones llevan metrajes encontrados que son proyectados y luego se reflexiona sobre su posible origen. Toda la información sobre este tipo de films, puede ser consultada en el blog http:// orphanfilmsymposium.blogspot.com/. En este sitio archivistas, académicos e investigadores discuten cuestiones vinculadas a la preservación de films que no están cubiertos por la protección de las legislaciones destinadas a la preservación del patrimonio audiovisual. A su vez este blog es el registro del Simposio que se realiza en el que académicos, archivistas, realizadores, curadores y técnicos se reúnen para proyectar, comentar y estudiar materiales marginados. El metraje encontrado que forma parte de estos films proviene de espacios 
totalmente ajenos a los archivos institucionales: mercados de pulgas, cestos de basura, colecciones personales, hallazgos en sitios de los más diversos. Así mismo los géneros que abarcan son muy amplios desde noticieros, films educativos, institucionales, de propaganda, pornográficos, amateurs, familiares, etnográficos, etc. Lo mismo sucede con los soportes de los mismos desde $8 \mathrm{~mm}$, Súper $8,16 \mathrm{~mm}$, etc. La práctica del found footage resignifica estas imágenes huérfanas porque a pesar de no modificarlas o intervenirlas, las expones en un contexto diferente generando una nueva mirada. El concepto de orfandad, viene siendo muy útil porque contribuyó a la institucionalización de las tareas de colección, conservación y acceso para una gran cantidad de materiales audiovisuales que históricamente han sido desplazadas u olvidados.

Continuando con esta línea del planteo de miradas diversas, que vienen desarrollándose sobre el universo audiovisual que no responde a las imágenes legitimadas e institucionalizadas, es importante destacar otra tendencia. Desde el año 2003 se lleva a cabo, durante la misma fecha pero en diversos lugares del mundo el Home Movie Day, http://www.homemovieday.com/. El objetivo de este evento es reunir a quienes quieran compartir sus viejas películas domésticas, quienes hayan descubierto cintas familiares y quieran compartirla con un público desconocido. De alguna manera este evento genera la exposición de una suma de memorias individuales y personales que pone en evidencia momentos similares de las vidas de las personas: desde los nacimientos, casamientos, cumpleaños, graduaciones, que pueden tener características diversas por cuestiones culturales pero que en definitiva son las mismas situaciones que vive cualquier ciudadano del mundo. Por otro lado entra en crisis el concepto de cine como espectáculo, al exponer imágenes íntimas que fueron registradas a modo de memoria privada, frente a la ceremonia del espectador de cine que se encuentra a oscuras en una sala de cine para presenciar un espectáculo audiovisual. El límite entre lo privado y lo público queda indefectiblemente superpuesto e invisibilizado.

La práctica del Found Footage fue ganando lugar e importancia en la programación de los festivales de cine, como ser BAFICl en Argentina y en España, Austria y Canadá además de Estados Unidos en dónde hay un festival dedicado a este tipo de cine, Found Footage Festival, http://www.foundfootagefest.com/ que trabaja con material en video exclusivamente en formato VHS. En este festival se proyectan materiales de lo más diversos géneros: capítulos de series televisivas, fragmentos de documentales, publicidades de televisión, etc. En Argentina, esta práctica está en pleno crecimiento; atribuido, por los especialistas Diego Trerotola y Leandro Listoriti, por un lado a las influencias que ejercen sobre los jóvenes cineastas, festivales como el BAFICI y la edición de publicaciones especializadas, como también por una realidad en la que estamos inmersos, atravesada por un mundo de imá- genes que circulan a través de las nuevas tecnologías protagonistas de nuestras vidas Todo comenzó con las videograbadoras caseras en los '80s, y se potenció en la actualidad con dispositivos cada vez más sofisticados pero al mismo tiempo más simples para el usuario común.

Con un teléfono móvil o con una herramienta como Youtube en Internet, todos podemos ser realizadores Found Footage, falta sólo tener la intencionalidad artística de que ese material sea exhibido como tal o inversamente esperar que esa intencionalidad se diluya con la vida cotidiana, dejando al Found Footage como una práctica artística del pasado.

Como aporte bibliográfico sobre el tema analizado, la literatura en español es escasa pero importante por la calidad del contenido y la investigación que la precede. En nuestro país, recientemente editado el libro ya citado Cine encontrado: ¿Qué es y adónde va el found footage? (2010) es un claro ejemplo de ésto. Los compiladores argentinos Leandro Listorti (realizador, periodista y programador de BAFICI Bs. As. Festival Internacional de 
Cine Independiente) y Diego Trerotola (realizador, periodista y programador de BAFICI), decidieron convocar y compilar tanto a autores como a realizadores vinculados con este práctica, para editar a través del festival el libro mencionado.

Ambos autores comparten la idea que el Found Footage no puede ser pensado como género o como se lo suele ubicar como un subgénero dentro del cine artístico o experimental, porque aquello que lo define como tal no es un adjetivo ni un sustantivo sino un verbo found, por lo tanto es un cine definido por un tipo de práctica, que en general es una práctica crítica. Es así como se lo relaciona de manera directa con las prácticas de los artistas dadaístas de principios del siglo XX, desde el collage hasta los ready made. La intención de los compiladores del libro no fue la de realizar un revisionismo histórico del Found Footage sino la de ofrecer un panorama amplio que incluyera distintas miradas sobre este fenómeno, por lo que convocaron a realizadores y teóricos. El límite que divide a ambos mundos del cine que dentro de otros géneros y prácticas está muy marcado, aquí se vuelve débil, ya que los realizadores con su práctica reflexionan sobre el lenguaje cinematográfico, por lo tanto hacer y pensar al cine Found Footage son actividades conjuntas, no puede darse la una sin la otra.

Otras de las publicaciones en español fue editada también en el marco de un festival de cine internacional, en este caso el Festival Internacional de Cine Documental de Navarra, 2009 como parte de la colección Punto de Vista. Su título es Metraje encontrado. La apropiación en el cine documental y experimental (2009) y el autor es Antonio Weinrichter. Dicho trabajo no está editado en Argentina pero puede ser solicitado vía Internet. Otros autores que han publicado sobre el tema son: - Eugeni Bonet (1993) Desmontaje: film, video/apropiación, reciclaje, Valencia: IVAM.

- Hausheer, Settele (1992) Found Footage Film, Luzern: VIPER.

- Wees William (1993) Recycled Images: The Art and Politics of Found Footage Films, Nueva York: Anthology Film Archives.

- VV.AA. (1998) Propuestas al margen: falso documental y metraje encontrado En Archivos de la filmoteca, Valencia: Paidós.

- Arthur Paul (2008) En busca de los archivos perdidos. En Archivos de la filmoteca 58. Valencia: Ediciones de la Filmoteca. Luego existen una serie de artículos en revistas especializadas como en blogs que tratan sobre el tema en cuestión y ellos son: - Brenez, Nicole, Cartographie du found footage, disponible en:

www.archives.arte.tv - Wees, William, Found Footage y el aura ambigua de Hollywood, Cinema Journal, Vol. 41, No. 2 (2002), trad. disponible en www.visionesmetaforicas.blogspot.com - Jacobsen, Udo, En busca del sentido perdido. En torno al found footage, revista electrónica Fuera de campo,

http://www.fueradecampo.cl/Articulos/foundfootage.htm Si bien el marco teórico será desarrollado en otra etapa de la exploración, resulta oportuno cerrar dicha presentación del objeto de estudio con los conceptos elaborados por Nicolás Bourriaud tanto en su libro Estética Relacional (2002, Paris: Presses du réel) como en Postproducción (2006, Bs. As., Adriana Hidalgo). El autor desarrolla un concepto interesante en relación a la definición que hace del artista contemporáneo como un inquilino de la cultura. Sostiene que en la posmodernidad las obras ya no tienen como meta formar realidades imaginarias, sino que por el contrario buscan constituir modos de existencia dentro de lo real ya existente. Afirma que las prácticas del bricolage y del reciclaje de lo cultural, son lo que sostiene al mundo de hoy. En relación al lugar que ocupa el receptor de este 
tipo de obras, el autor habla de la existencia de un encuentro entre el público y la obra, obra que al formar parte de una sociedad espectacularizada se percibe en grupo, generando así una elaboración colectiva del sentido. Es así como habla de arte como estado de encuentro, como el lugar en dónde una propuesta artística genera una relación dinámica entre la obra y el público y entre el público mismo. Sólo desde este lugar, propio de la posmodernidad es posible comprender la expansión de una práctica como la del Found Footage. En relación al concepto de Postproducción lo define como un término técnico utilizado en el mundo de la televisión, el cine y el video y designa el conjunto de procesos efectuados sobre un material grabado: el montaje, la inclusión de otras fuentes visuales o sonoras, el subtitulado, las voces en off y los efectos especiales. Los artistas que insertan su propio trabajo en el de otros llevan a destruir la tradicional distinción entre producción y consumo, creación y copia, ready-made y obra original "la materia que manipulan ya no es materia prima" (2006).

Es en este punto en donde entra en cuestión lo planteado en la introducción de dicho estudio: la práctica del Found Footage implica una crítica frente al medio, por lo tanto la ejercitación por parte de los alumnos de dicha práctica implicará un conocimiento crítico y reflexivo sobre el medio y sobre el concepto de la creación artística que replantea supuestos filosóficos instalados en la cultura y educación occidental basada en la idea de la creación artística definida por la creación de algo nuevo y único que se plasma materialmente en la obra de arte original y nueva.

\section{Encuadre teórico}

Uno de los autores fundamentales para desarrollar la exploración de la tendencia del Found Footage es Nicolás Bourriaud citado previamente por sus textos Postproducción (2006, Bs. As., Adriana Hidalgo) y Estética Relacional (2002, Paris: Presses du réel). En este último reflexiona sobre el concepto de sensibilidad colectiva en la que se inscriben las nuevas formas de la práctica artística. En el mismo trabajo analiza las características principales de los nuevos modos de producción artística basados en la utilización de herramientas basadas en obras y estructuras formales preexistentes. Bourriaud cita algunos ejemplos de obras de artistas contemporáneos que expresan claramente este nuevo modo de producción, uno de ellos es 24 hour psycho (1997) obra del video artista Douglas Gordon que consiste en una proyección en cámara lenta del film de Alfred Hitchcock Psicosis, de modo que llega a durar veinticuatro horas. Estas prácticas artísticas se caracterizan por el hecho de recurrir a formas ya producidas. La voluntad de los artistas es inscribir la obra de arte en el interior de una red de signos y de significaciones en lugar de considerarla como una forma autónoma u original. De esta forma desarrolla el concepto contemporá- neo de postproducción en su texto citado anteriormente, para definir las intenciones de los artistas actuales como programadores y no como creadores de algo nuevo "los artistas actuales programan formas antes que componerlas, más que transfigurar un elemento en bruto (la tela blanca, la arcilla, etc.), utilizan lo dado" (2006). Otro de los conceptos elaborados por este autor, que apoyan el marco teórico de la investigación es el de apropiación de la cultura. Las prácticas artísticas contemporáneas implican una acción de apoderarse de todos los códigos de la cultura, de las formalizaciones de la vida cotidiana, de todas las obras del patrimonio mundial y el objetivo es hacerlos funcionar en otro contexto. De alguna forma, ser un artista actual implica un aprendizaje en relación a servirse de las formas, habitarlas y apropiarlas.

La idea de la cultura como la de un itinerario por recorrer es otra de las ideas desarrolladas por Bourriaud que ayudan a definir el marco teórico de la investigación exploratoria de una tendencia como la del Found Footage. En este punto vincula la práctica del DJ, la del web surfer y la de los artistas de la postproducción. Los tres son definidos como semionautas ya que antes que nada producen recorridos originales entre los signos. El DJ activa a su manera, la historia de la música copiando y pegando trozos sonoros, poniendo en relación productos grabados. El usuario de Internet crea su propio sitio conducido a recortar las informaciones obtenidas. El concepto de la cultura del uso atraviesa este trabajo de Bourriaud. Es así como la obra de arte supera su papel tradicional como simple receptáculo de la visión del artista para pasar a funcionar como un agente activo, como un ente que dispone de autonomía y de materialidad en diversos grados ya que su forma, la creada por el artista original puede variar. El autor concluye afirmando que el arte vendría así a contradecir la cultura pasiva que 
opone en el mercado a los consumidores a las mercancías. Por lo tanto, en la cultura del uso el sentido nace de una colaboración, una negociación entre el artista y quien va a contemplar la obra.

Otro autor esencial para el encuadre teórico de dicha investigación exploratoria es Guy Debord por su obra La sociedad del espectáculo (1995, Bs. As.: La Marca). Es pertinente también, porque el mismo autor filmó una película de Found Footage que denominó La societé du spectacle (1973) como transposición de su tesis. En su contenido trabaja con imágenes preexistentes, por lo tanto rechaza la producción de imágenes nuevas. La utilización de imágenes ya registradas por otros y su consiguiente manipulación le sirven al autor para demostrar el dominio y la alienación que éstas ejercen sobre el espectador.

Todas estas imágenes van acompañadas por una voz over que enuncia la tesis del libro que la película transpone. Indicando cómo mirar las imágenes ancla el sentido y señala el modo que hay que situarse frente a aquello que vemos, con el fin de neutralizar el poder cosificante de las imágenes espectaculares, pero también los hace por su ruptura de toda posibilidad de unir sintagmáticamente los planos. Si se analiza el fenómeno cultural desde parte de la tesis del autor que sostiene que el espectáculo no es un conjunto de imágenes sino una relación social de personas mediatizadas por imágenes, el universo del cine sería aquel que pone en manifiesto de manera explícita aquella relación. Por este motivo, resulta pertinente nombrar el afiche del film precedente con una cita de Debord "El cine también, debe ser destruido". La práctica del Found Footage destruye la lógica del cine clá- sico y narrativo, pero también destruye la lógica del artista como creador de algo nuevo, original que genera el concepto de aura. Es así como la negación de sí mismo, siguiendo la propuesta de Debord. Como el espectáculo es una visión del mundo que se ha objetivado, la manipulación y destrucción de esas imágenes permite desobjetivarlo, desalienarlo. Por otro lado con esta práctica autodestructiva, logra poner de manifiesto cómo el espectáculo constituye el modelo presente de la vida socialmente dominante.

Por otro lado, resulta pertinente observar el caso analizado en la presente exploración, bajo la lupa teórica de Los límites de la interpretación (1998, Barcelona: Lumen) de Humberto Eco. Estos conceptos son necesarios para poder analizar el fenómeno, desde la perspectiva del espectador. Las obras del Found Footage son obras experimentales, por lo tanto rompen desde su propia definición con la noción de obra de arte legible que debe emitir un claro mensaje al espectador. El autor sostiene que todo texto, como toda obra arte, pueden ser consideradas como una máquina que produce una deriva infinita de sentido. Las obras del Found Footage revierten el sentido de las imágenes tomadas en otro contexto y con otros fines, por lo tanto los espectadores poseen un gran trabajo de interpretación que pueden encuadrarse dentro de los debates propuestos por el autor. En torno a ésto sostiene por un lado que es necesario buscar en el texto lo que dice con referencia a su misma coherencia contextual y a la situación de los sistemas de significación a los que se remite. Por otro sostiene que es necesario buscar en el texto lo que el destinatario encuentra con referencia a sus propios sistemas de significación y/o con referencia a sus deseos y pulsiones arbitrarias. El espectador especializado del Found Footage, debe poseer el conocimiento de las características propias de esta tendencia, en la que el creador se apropia de fragmentos de películas sobre las que va a imprimir su mirada. Esta mirada siempre pone en crisis, en contradicción el uso, la forma y el contenido del original. Por lo tanto el destinatario de estas obras deberá realizar un doble trabajo, por un lado encontrar las referencias con coherencia contextual del original, y por otro lado encontrar las referencias a sus propios sistemas de significación a partir de la segunda lectura realizada por el director. 
Uno de los conceptos fundamentales para poder abordar el análisis de esta tendencia es el desarrollado por Eugeni Bonet sobre la película de montaje. Desarrolla este concepto para las películas basadas sustancialmente en un material preexistente, de archivo u otra procedencia, reutilizado para generar un nuevo discurso. El término película lo utiliza porque dicha definición debe abarcar diversos soportes, contextos y tránsitos, por este motivo no implementa el término film que refiere a un tipo de material fílmico y analógico. El nombre película permite hacer referencia no sólo al cine, la televisión y el video sino también a todo aquello que concierne a los sistemas multimedia donde película designa todo contenido que se ampara en una secuencia de imágenes en movimiento, sea en un disco digital compacto o en la red. Bonet continúa su desarrollo en relación a la expresión cine de montaje haciendo hincapié en el aporte de los cineastas rusos. Esta vanguardia artística desarrollada durante la revolución socialista, logró asociar la idea de la técnica de la fábrica con el montaje como la cirugía de la película. En su desarrollo histórico por el concepto de cine montaje, Bonet cita otro momento importante a mediados del siglo XX, cuando el material y el documental de archivo hallan una gran demanda en la televisión. Esta situación se ve reforzada por la incursión del video doméstico y el ordenador multimedia que habilitan la familiarización de todos con el archivo público de las imágenes. De esta manera se ha ido afirmando otra clase de compilación y cultura de los archivos, desarrollado al margen de los archivos institucionales y las prácticas artísticas experimentales. Otro concepto desarrollado por el autor citado, fundamental también para la presente investigación exploratoria de la práctica del Found Footage, es el de desmontaje. Este término hace referencia a varias facetas pertinentes para este trabajo. Por un lado la idea de desmontaje remite a un reverso de la práctica más habitual de montaje y su sentido constructivo. Por otro lado hace referencia a otras expresiones como la deconstrucción. En este sentido, se puede vincular la práctica del Found Footage con las poéticas del objeto encontrado, vulgar, episódico, readymade, el assemblage del arte norteamericano y el scratch video británico. Estos films también son analizados desde la designación collage, en las mismas generalmente no hay comentarios en off como tampoco se apela a un tono instructivo o didáctico. Se prima por que las imágenes se expresen por sí mismas, por el aporte realizado por el director desde el montaje o desmontaje, continuando con el sentido de que aquello que la nueva obra nos dice suele ser bastante distinto a aquello que pretendían los materiales de partida.

Otro concepto retomado por Bonet, del autor Richard Prelinger, es el de films efímeros como aquellos que sirven de material de partida de los realizadores del Found Footage y que están representados por los géneros de producción educativa, corporativa o institucional, el reportaje industrial o promocional, la publicidad y la propaganda y los descartes y excedentes de productos ya en sí concebidos para una vigencia perecedera. Para cerrar con el aporte teórico de Eugeni Bonet al estudio de la práctica del Found Footage y su desarrollo del concepto de desmontaje documental, se puede afirmar que este tipo de montaje se opone al documental de montaje que se distingue por sus propósitos de objetividad, neutralidad y reseña histórica. Esta oposición se basa en los criterios de subjetividad, postura crítica, interpelación de los modos de representación y de la interpretación semiótica única de las imágenes propios del desmontaje documental. Estas imágenes se encuentran liberadas de sus destinos, propósitos y sentidos originales. Es así como, a través del desmontaje, se desvela un subtexto y connotaciones imprevistas por los realizadores originales. Otros de los autores que aportan conceptos fundamentales para el desarrollo de la presente investigación exploratoria son Paul Young y Paul Duncan con su texto Cine artístico (2009, Colonia: Taschen). En el capítulo que los autores desarrollan la noción de cine de collage y metraje encontrado, hacen referencia a la característica propia de la producción artística contemporánea, signada por prácticas como la del collage, el ensamblaje y el arte de los objetos encontrados. En relación al concepto de collage plantean ciertas dificultades en el caso del cine, ya que por 
naturaleza es un medio basado en el tiempo, por lo tanto, únicamente puede presentar tomas a modo de secuencia en lugar de simultáneamente. Para lograr una solución a este problema, plantean una definición sumamente importante para el marco teórica del presente trabajo. La definición de collage propuesta parte de la idea del proceso de usar objetos reales encontrados para un plano pictórico y plástico y para el cine de metraje encontrado, consiste en tomar material preexistente y transformarlo mediante el montaje y la yuxtaposición. De esta manera, se puede pensar en un equivalente cinematográfico del concepto del collage pictórico. En torno al concepto de posmodernidad en la producción artística, Young y Duncan citan a las décadas de 1970 y 1980 como una nueva era de apropiación de imágenes que influyó fuertemente en los cineastas que trabajan con el collage. Un ejemplo interesante para fundamentar dicha reflexión fue la experiencia de Terry Cannon A Show for the Eyes (1981), quien apropiándose del concepto de arte por correspondencia o mail art generó una propuesta desde la cual cineastas de todo el mundo donaron breves fragmentos de metraje para la creación de una obra colectiva. Otro concepto ya analizado anteriormente, que estos autores trabajan es el de la práctica del video scratching. Definen a la misma como la práctica con la que el artista manipula metraje de la misma manera que un pinchadiscos de DJ, los artistas Martin Arnold, Steina y Woody Vasulka iniciaron esta práctica en la década del 1980. Un ejemplo claro de esta práctica es la obra de Kevin Hanley Recounting a Dancing Man (1998). En la misma, el artista utiliza un fragmento de cuatro minutos de un claqué de Fred Astaire en The Belle of New York para investigar un programa de software que mezcla el segmento de manera aleatoria. Los movimientos de Astaire se detienen y arrancan como si un pinchadiscos realizara scratches con un disco, lo que a su vez crea una banda sonora original propia.

Otro de los conceptos interesantes a la hora de definir el marco teórico del presente trabajo exploratorio, es el desarrollado por Diego Trerotola en su capítulo del libro Cine encontrado: ¿Qué es y adónde va el found footage? (2010, Bs. As.: BAFICI), con la denominación de material reencontrado. Para describir dicho concepto trabaja con el análisis de una obra citada previamente en este trabajo, Wound Footage (2003/2009) del realizador Thorsten Fleisch. El autor sostiene que la propuesta de Fleisch es totalmente renovadora y ésto se da por su status de post-cine. Con este término Trerotola se refiere al mejor Found Footage que interviene después de que el objeto ya cumplió con su función cinematográfica. El realizador le da una vida diferente al material originario encontrado, a partir del aporte de una propuesta estética o conceptual propia que reactiva un material que se encuentra inerte. Por lo tanto, el concepto de material reencontrado hace referencia a un material doblemente encontrado. Esto se debe a que en una primera etapa Fleisch encontró un material en Súper 8 que lo sometió a un experimento, luego de esta etapa sometió al material a una serie de intervenciones y ataques, entre ellas fue filmar en video el soporte fílmico original para guardarlo luego en el ordenador. Varios años después, ese material digitalizado fue nuevamente intervenido, concluyendo así la obra Wound Footage en el año 2009. Otro autor fundamental, en lo que concierne a la elaboración de conceptos que reflexionan sobre la práctica del Found Footage es William Wees. El mismo, en su texto Recycled Images: The Art and Politics of Found Footage Films (1993, Nueva York: Anthology Film Archives), desarrolla el concepto de autorreferencialidad. El autor afirma que más allá de la acción que elija el realizador en relación al film encontrado, ya sea que la remonta, re-filma o revela de nuevo usando diferentes técnicas, el resultado final es siempre el mismo. El espectador observa esta creación como una película encontrada, como imágenes recicladas. Esta autorreferencialidad es una peculiaridad del Found Footage. Este metraje se somete a una lectura más analítica por parte del receptor, en relación a la recepción que se tuvo de su proyección original. El nivel de mirada analítica por parte del receptor, será más elaborado en función de la diversidad de materiales con los que se componga el film final: noticieros y documentales, películas propagandísticas, educacionales e 
industriales, reportajes turísticos, imágenes de archivo, dibujos animados, películas pornográficas, antiguas películas mudas, largometrajes de Hollywood, anuncios y concursos de televisión, etc. Es así como la autorreferencialidad se afirma, ya que el film Found Footage da por supuesto que su receptor maneja los códigos y convenciones de cada uno de los géneros, formatos, estilos y épocas de esos materiales preexistentes. Wees sostiene que esta diversidad de fuentes, tiene su razón de ser a partir de las decisiones que tome el realizador desde el montaje. Es así como desarrolla diferentes posturas, que el realizador puede adoptar frente a este material encontrado. Por un lado nombra un tipo de montaje basado en una asociación basada en una especie de continuidad narrativa, en la que un plano se relaciona con otro desde una lógica narrativa creada por el realizador. Otro proceso de asociación de imágenes vincula a los planos de un modo conceptual, metafórico y en algunos casos esta asociación está basada en cuestiones gráficas y plásticas de la imagen. Ambos procesos asociativos, se apoyan, según Wees, en otro elemento fundamental a la hora de dotar de sentidos la obra final, que es el sonido. Es así como cita a Eisenstein en relación al concepto de montaje vertical para referirse a la yuxtaposición puntual de las bandas de sonido e imagen.

Para cerrar el encuadre teórico de los autores seleccionados para la elaboración del mismo, es oportuno citar a Lev Manovich y su obra El lenguaje de los nuevos medios de comunicación (2006, Bs. As.: Paidós). Un concepto imprescindible para comprender el fenómeno del Found Footage es el de cultura del remix. Como característica particular de la cultura contemporánea en sus más diversas manifestaciones como la música, la moda, el diseño, el arte, las aplicaciones web, etc., se encuentran enmarcadas dentro de una lógica de producción que corresponde al remixes, fusiones, ensamblajes y collages. En su descripción del concepto de remix, hace una genealogía en su relación originaria con el mundo de la música. Partiendo de la posibilidad de disponer de las diferentes partes de una canción, las voces y los instrumentos por separado, se habilita la manipulación de la misma en sus diferentes niveles. Es así como es factible hablar de un re-mix de la canción a partir del cambio del volumen de algunas pistas o de la sustitución de nuevas pistas por las viejas, etc. Este término que nació del mundo de la música, desde la década del 2000 se extendió a diferentes manifestaciones y campos de la cultura contemporánea. Por lo tanto esta práctica se extiende también al campo audiovisual partiendo de la idea que el remix típico se caracteriza por combinar contenidos dentro del mismo medio como contenidos de diferentes medios. Manovich afirma que los remix con contenido de diferentes medios son muy comunes en la cultura de la imagen en movimiento. Sin embargo en este punto, necesita desarrollar un nuevo concepto, el de remix profundo: "Lo que se remixa hoy no es sólo el contenido de los diferentes medios, sino fundamentalmente sus técnicas, sus métodos de trabajo y las formas de representación y de expresión" (2006). El trasfondo de esta práctica es el resultado de una serie de soportes como un software, el cine, la animación, los efectos especiales, etc. Los mismos conforman, según Manovich, un metamedio como marco general de las obras contemporáneas. Esta obra puede utilizar todas las técnicas o alguna de ellas para su elaboración. De este modo, afirma que la interacción que se da entre técnicas de distintos medios es una característica clave en la cultura de las imágenes en movimiento, por este motivo desarrolla el concepto de remix profundo para diferenciarlo del remix musical que implica la interacción de contenidos de un mismo medio.

Una de las peculiaridades de la práctica Found Footage es la incorporación de diferentes técnicas (la gráfica, efectos especiales, animación digital, etc.) para la elaboración de sentido en sus obras. Es así como el concepto de remix profundo elaborado por Manovich resulta esencial en el análisis de dicha tendencia.

El avance de la presente investigación exploratoria, en relación a los autores y obras citadas en este encuadre teórico, se da por el enfoque realizado sobre el mismo. Se diferencia de los textos nombrados en que concentra 
la mayor cantidad de información posible en un mismo trabajo. Por lo tanto las miradas, reflexiones y posturas frente a la práctica del Found Footage que han sido elaboradas en los últimos años, están presentes en este trabajo que hace hincapié en la producción contemporánea argentina. Muchas de las obras citadas fueron realizadas en otros países, por lo tanto los objetos de estudio se basaron en producciones fundamentalmente estadounidenses y europeas.

\section{Organización de la investigación}

a) Este trabajo de exploración profesional ha sido desarrollado individualmente, sin embargo más adelante se realizará una propuesta en relación a posibles modelos de trabajo práctico para realizar con alumnos de las diferentes carreras de la Facultad de Diseño y Comunicación.

En relación a la estructura que se tuvo en cuenta para la organización de la investigación, partiendo de la situación objetiva de ser una investigación individual realizada sin la participación de un equipo de investigadores, como tampoco con el trabajo de un grupo de alumnos.

Se planteó así en tres etapas:

1. Relevamiento documental. Tanto del material audiovisual como teórico.

\section{Realización de entrevistas a realizadores de la práctica Found Footage.}

\section{Escritura del texto del presente ensayo de investigación.}

1. Relevamiento documental: En la primera etapa planificada, fue en donde se encontró la mayor dificultad. Las características propias del objeto de estudio, la práctica audiovisual del Found Footage, determinaron esta dificultad. En primer lugar la problemática anteriormente mencionada en relación a la poca publicación en español y editada en el país, que existe sobre el objeto de estudio. Muchos de los textos que forman parte del marco teórico y de la bibliografía, son textos en otras lenguas básicamente en inglés. Otros tantos, pueden hallarse únicamente en versiones digitales, o en blogs especializados en el tema. El material teórico editado en el país es escaso pero de muy buen nivel, tanto por la rigurosidad de las investigaciones que lo respaldan como por la autoridad en el tema que poseen los autores de los mismos. La práctica del Found Footage es experimental y artística, por lo tanto no forma parte de un circuito comercial y masivo. Esta marginalidad del objeto se refleja en su poca visibilidad dentro del campo intelectual.

Si se toma el concepto de campo intelectual que desarrolla Pierre Bordieu en Campo intelectual y proyecto creador, es necesario partir de la idea de la existencia de una relación entre el artista y su obra, esta relación es afectada por el sistema de relaciones sociales dentro de la cual tiene lugar el acto creativo del artista. Por lo tanto esta relación va a estar determinada por la posición que el artista ocupe dentro de la estructura del campo intelectual. Desde la modernidad la lógica que gobierna este campo es específica y es la competencia por la legitimidad cultural. Otro concepto fundamental para la comprensión del campo es el de autonomía: a medida que el campo intelectual logra autonomía de otras esferas, el artista moderno declara su independencia del público. Por lo tanto la noción del artista como genio creador, que vive con sus propias reglas al margen de cualquier interés por el éxito comercial fue lo que instauró el campo intelectual en la modernidad, con los poetas románticos básicamente. Para analizar el caso seleccionado del Found Footage, resulta pertinente considerar ciertos rasgos característicos del mundo de la cinematografía contemporánea. Para poder comprender las 
particularidades del campo se puede decir que existen básicamente dos circuitos: el comercial y el cine arte o experimental que tiene su propio circuito desarrollado en festivales, ciclos de cine en museos, escuelas de cine, etc. La práctica del Found Footage como tendencia experimental se ubica claramente en el circuito del cine arte, no comercial. Por lo tanto se analiza el lugar que ocupa dentro del campo de cine, entendido como cine-arte.

Durante varios años, las películas fruto de estas prácticas no tuvieron visibilidad en aquellos eventos y circuitos legitimadores desde festivales de cine internacionales hasta en las programaciones de salas de cine arte locales. En Argentina recién en el 2010 el Found Footage logró su lugar reconocible y enmarcado dentro de una sección específica de la programación del BAFICI (Buenos Aires Festival Internacional de Cine Independiente) y la consiguiente publicación de un libro mencionado previamente en este ensayo. El investigador alemán Antonio Weinreichter, citado previamente, publicó recientemente un libro en el que habla sobre la larga historia de indiferencia y desprecio hacia el Found Footage, hasta que después de más de veinte años y habiendo proliferado como práctica del cine underground y experimental, fue aceptado por el campo, como una forma legítima en textos teóricos y críticos.

2. Entrevistas: En relación a esta etapa, la entrevista realizada a los compiladores del libro Cine encontrado: ¿Qué es y adónde va el found footage? (2010, Bs. As.: BAFICI.), Diego Trerotola y Leandro Listorti, resultaron trascendentales a la hora de enmarcar histórica y socialmente al objeto de estudio planteado en el presente trabajo. Otra de las entrevistas realizadas, que resultaron de gran interés por haber aportado la visión de un realizador argentino contemporáneo como ser Gustavo Galuppo, brindó al trabajo un marco conceptual y un rico panorama, más vinculado a la realización audiovisual argentina y contemporánea.

Según el autor Jesús Galindo Cáceres, la entrevista cualitativa proporciona un instrumento heurístico para combinar los enfoques prácticos, analíticos e interpretativos implícitos en todo proceso de comunicación. En relación a la importancia dada, por este autor, a la técnica de la entrevista, se encuentra legitimada por su propia historia relativamente corta. Su origen está ligado al desarrollo e instauración del sistema capitalista, y en concreto, al proceso de modernización de las relaciones en el espacio público a través de las recientemente creadas ciencias sociales y la circulación de la prensa de masas. El origen de la entrevista deriva de la divulgación de los usos periodísticos. En este trabajo se han combinado ambos tipos de entrevistas: la periodística y la desarrollada luego por las ciencias sociales en las tareas de investigación. Como en ambos casos entrevistados, los realizadores son a su vez investigadores sobre el tema, resultó pertinente el uso de ambas.

En relación al autor citado previamente, se puede ubicar el origen de la entrevista propia de las investigaciones sociales al iniciarse la década de los treinta. El proceso de institucionalización social en Estados Unidos de algunas disciplinas como la psicología o los estudios sociológicos, abrieron el marco de integración de nuevas técnicas como la entrevista. Es así como en este período la entrevista se generaliza en dos usos, que han distinguido hasta hoy lo cualitativo y lo cuantitativo, lo primero en relación a la entrevista extensiva (entrevista de opinión) y lo segundo en relación a la entrevista intensiva (entrevista abierta). Este proyecto por enmarcar un objeto de estudio propio de una ciencia social como es el arte audiovisual, generó la planificación de entrevistas de opinión como herramienta básica de una investigación cualitativa. Continuando con Jesús Galindo Cáceres, "se puede afirmar que una definición de entrevista es aquella que se entiende por una conversación entre dos o más seres humanos (entrevistador y entrevistado) cuya finalidad es lo que en verdad le otorga carácter. La entrevista es una conversación que establecen un interrogador y un interrogado para un propósito expreso" 
(1998). Algo sumamente importante en el uso de este tipo de herramienta de investigación, es que a diferencia de la conversación común toda entrevista se construye a partir del derecho a la pregunta. Por lo tanto, los interlocutores no mantienen en ningún modo posiciones simétricas. La entrevista está mediatizada por la necesidad pragmática que justifica el encuentro conversacional. Por otro lado es importante tener en cuenta que el manejo de la técnica de la entrevista reclama conocimiento del contexto comunicativo en el que se produce la interacción entre los hablantes.

En el caso del presente trabajo, el contexto comunicativo se vio retroalimentado por la rica interacción de información dada en los diálogos, ya que la conversación se dio de manera fluida debido al manejo de la información tratada.

Una vez que la información ha sido recopilada, analizada y organizada según su fuente y tema pertinente, se desarrolló la escritura del presente texto.

b) Estudiantes: Como se afirmó previamente, si bien el presente ensayo no se realizó con la participación de alumnos, ya sea en su confección o en la realización de algún trabajo práctico en alguna de sus instancias, se realizará una propuesta para tomar como modelo de posibles futuros trabajos de campo sobre el tema desarrollado.

Tomando en cuenta al diseño y al arte como las disciplinas que atraviesan las diferentes carreras que forman parte de la Facultad de Diseño y Comunicación, es de suma importancia poder contar con modelos de trabajos prácticos para que los alumnos apliquen los conceptos desarrollados durante las materias cursadas.

Partiendo de un marco teórico propuesto por el autor Donald Shön (1992) quien sostiene que el conocimiento es un proceso que se da en la acción. El conocimiento está en la acción, lo revelamos a través de nuestra ejecución espontánea y hábil, y paradójicamente somos incapaces de hacerlo explícito verbalmente. Continuando con su planteo, es posible afirmar que podemos reflexionar sobre la acción para descubrir cómo nuestro conocimiento en la acción puede haber contribuido a un resultado inesperado. Nuestra acción de pensar sirve para reorganizar lo que estamos haciendo mientras lo estamos haciendo, por lo tanto estamos reflexionando sobre la acción. Es así que la necesidad de desarrollar habilidades en los alumnos para que puedan articular teoría-práctica, es un objetivo fundamental en el ejercicio de la docencia universitaria. Esta vinculación de la teoría y la práctica, será fundamental en el ejercicio de la profesión. Según Shön (1992), el conocimiento en la acción de un profesional está incrustado en el contexto estructurado a nivel social e institucional que comparte una comunidad de prácticos. El conocimiento en la práctica se ejercita en los ámbitos institucionales propios de la profesión. Resulta imprescindible que los estudiantes aprendan un tipo de reflexión en la acción que vaya más allá de las reglas existentes, por el establecimiento de nuevos métodos de razonamiento y por la construcción y comprobación de nuevas categorías de conocimiento, estrategias de acción y maneras de formular los problemas.

\section{Propuesta}

El objetivo de la propuesta de trabajo será la de desarrollar un trabajo de apropiación de un conocimiento teórico como ser el de la historia y características principales de la práctica del Found Footage a partir de la realización de un trabajo práctico que consista en la realización de un cortometraje realizado con los principios básicos de la práctica del Found Footage: reunión de material preexistente y de autoría no propia, y la postproducción que reúne ese material seleccionado a partir de una idea o concepto propio y diferente al original. 
Las materias que intervengan en dicho proyecto tendrán que ser aquellas que por su contenido se justifique la vinculación con la práctica analizada en el presente trabajo.

En relación a la metodología a implementar para el proyecto propuesto, podría ser adaptada a las necesidades y requerimientos de cada materia como intereses del profesor, pero básicamente consistirá en el trabajo organizado por cada profesor como guía y coordinador de los trabajos que serán desarrollados en equipos de no más de cuatro integrantes.

En este punto resulta pertinente citar al autor Miguel Ángel Zabalza (2010) quien sostiene que existen diferentes modos de entender el proceso de aprendizaje: el aprender como comprender el significado y sentido de lo que se aprende (aprendizaje significativo), el aprender como el hacerse consciente de cuestiones problemáticas (aprendizaje reflexivo), el aprender el aprender como ir construyendo conocimientos nuevos a partir de los que ya se poseen (aprendizaje constructivista). El concepto de competencias, desarrollado por el autor citado, alude a un enfoque en el que aprender significa ser capaz de "usar el conocimiento" para elaborar un producto, resolver un problema, redactar un informe, etc. Es con este último enfoque con el que se propone el presente modelo de trabajo práctico para abordar dentro del contenido de las asignaturas pertinentes, el objeto de estudio trabajado durante el presente ensayo.

Continuando con lo propuesto por el autor Zabalza (2010), este modelo de trabajo práctico, permite al docente llegar a completar un proceso normal de aprendizaje que podría sintetizarse en ocho etapas: 1) se recibe una nueva información, 2) de esa información unas cosas se entienden mejor, normalmente, y otras no tanto quedando así lagunas en la comprensión, 3) es necesario subsanar estas lagunas con un nueva búsqueda de información y explicaciones, 4) una vez entendida la cuestión se precisa movilizar ese conocimiento para aplicarlo a alguna nueva actividad, 5) la aplicación generará nuevas dudas y consultas, 6) estas dudas serán resueltas a través de nuevas informaciones y explicaciones, 7) la transferencia permitirá comprobar que el aprendizaje va más allá de una aplicación mecánica a una situación concreta y es así como finalmente se llega a 8) la meta de un aprendizaje profundo y bien asentado.

El eje conceptual que atraviesa estas nociones sobre el buen aprendizaje, está centrado en la integración de la teoría y la práctica, ya que aprender significa ser capaz de movilizar y usar los conocimientos conceptuales para poder desarrollar procesos prácticos que suponen la aplicación de aquellos.

Actividades propuestas para el desarrollo del proyecto: - Individuales: a) Realizar un listado sobre temas sociales, políticos o artísticos que interesen personalmente.

b) Exponerlo en clase.

c) Reunirse en grupos por intereses comunes.

En esta instancia el objetivo principal es que el alumno se apropie de sus intereses personales y que a partir de este objetivo conforme grupos de trabajo y no lo haga por afinidad por amistad, generando trabajos menos interesantes por la falta de compromiso e involucramiento con las temáticas elegidas. Por otro lado, de esta forma, se abriría un espacio para que los alumnos expresen sus intereses más personales, generando así un espacio de debate en el que se compartan ideas y reflexiones sobre diferentes temas. 
- Grupales: a) A partir de un eje temático (por ejemplo "la violencia de género"), realizar un relevamiento de archivos audiovisuales que traten de alguna manera el tema.

b) Realizar en 2 instancias una exposición sobre los diferentes archivos encontrados y seleccionados para debatir sobre aquellos que resulten más pertinentes para la selección final y su posterior edición.

c) La entrega final consiste en la realización de un cortometraje de 3 a 5 minutos a partir de un trabajo de edición a partir de la técnica del Found Footage desde el marco teórico trabajado en clase.

El objetivo principal de estas actividades grupales, es el de la articulación efectiva entre la teoría desarrollada desde el marco teórico dado en clase sobre la temática del Found Footage, y la práctica de la realización audiovisual a partir de la cual los alumnos podrán experimentar personalmente los pasos e instancias de la práctica citada. Lo interesante es que el producto final reflejará las lecturas y reflexiones personales de los alumnos sobre temáticas que resultan interesantes para continuar desarrollando en otras instancias profesionales.

\section{Cronograma}

Para poder planificar los tiempos dedicados a cada una de las etapas de la presente investigación, es necesario poder realizar un desglose de las mismas, agrupándolas de la siguiente manera:

1. Relevamiento documental. Tanto del material audiovisual como teórico.

2. Realización de entrevistas a realizadores de la práctica Found Footage.

3. Escritura del texto del presente ensayo de investigación.

4. Trabajo práctico realizado con alumnos (propuesta).

- Relevamiento documental: Esta etapa se planificó previamente a la escritura del ensayo con un mínimo de dos meses de duración, pensado como tiempo necesario para la búsqueda de información tanto teórica como audiovisual sobre el tema investigado. Sin embargo, no finaliza ante el comienzo de la escritura del texto sino que permanentemente, se va ampliando, modificando y reorganizando en función de los nuevos materiales que se van encontrando a lo largo del proceso de escritura.

\section{Duración: 2 meses.}

- Entrevistas: esta etapa, previamente analizada, se trabaja independientemente del proceso de re recopilación de material. De todas formas, resulta muy importante, lograr recolectar la mayor cantidad de información necesaria sobre los entrevistados, para poder llegar al objetivo del generar entrevistas dinámicas y ricas en contenido a analizar en la etapa posterior de la escritura.

Duración: 2 meses - Escritura del texto: esta instancia continúa en proceso de desarrollo.

Duración: 6 meses. 
- Trabajo práctico realizado con alumnos (propuesta detallada anteriormente): el tiempo estipulado para cada una de las instancias del trabajo con los alumnos es la siguiente: a) Actividades individuales. Duración: 2 clases, 2 semanas.

b) Actividades grupales.

- Relevamiento documental: 2 clases, 2 semanas.

- Exposición sobre el proceso de trabajo: 2 clases, 2 semanas.

- Realización del cortometraje: 3 clases, 3 semanas.

- Entrega final - Duración total: 7 semanas

\section{Evaluación}

La propuesta de trabajo sobre el estudio de la práctica Found Footage se divide en dos instancias claramente diferenciadas, por un lado por el aprendizaje de la historia, teoría y crítica de la misma, y por otro lado la instancia práctica de realización de un cortometraje grupal, a partir del cual los alumnos puedan aplicar los conocimientos teóricos aprendidos durante el estudio del tema. Por tal motivo, los mecanismos de evaluación de los trabajos serán organizados de acuerdo a la actividad a evaluar.

En relación a los textos y al material teórico sobre la temática del Found Footage, se sugiere tener en cuenta, ciertos conceptos desarrollados por el docente José Luis Coraggio (2004). El mismo sostiene la importancia de que los alumnos conozcan los criterios del docente al evaluar. El objetivo es que los alumnos no se encuentren en desventaja en la primera evaluación y se encuentren reprobados o fuera de los límites de aprobación de la actividad. Es por ésto, que el autor citado, afirma que es importante anticipar adecuadamente la naturaleza, alcances y objetivos de las evaluaciones, minimizando así el efecto sorpresa. Un recurso interesante para tener en cuenta, a la hora de evaluar los contenidos teóricos desarrollados en los textos, es la de anticipar un número importante de preguntas que se vinculen al desarrollo concreto del curso. A partir del seguimiento de guías de lecturas, se busca sacar al alumno de la lectura pasiva del texto y también desarrollar la capacidad de los mismos de plantear preguntas nuevas y de pensar libremente la respuesta a preguntas que no estaban contenidas en el texto. Es posible también advertir a los alumnos que quien este en condiciones de trabajar bien esas preguntas, estará en condiciones de superar la evaluación final.

El desarrollo de estas guías de lecturas en cada clase, será aplicada al análisis de un texto teó- rico. La devolución de dichas correcciones, es recomendable realizarlas oralmente al grupo completo. Continuando con la argumentación de Coraggio, es interesante rescatar que una vez realizada la evaluación es importante que cada alumno o grupo de alumnos, sepa dónde se equivocó o dónde logró una buena producción, o qué fue evaluado como conocimiento insuficiente o como creación destacable por el docente. La devolución oral contribuye que se hagan públicas las observaciones a todos los alumnos, sin necesidad de personalizar.

Un método a tener en cuenta para la corrección de dichas guías a tener en cuenta es la de realizar un listado de notas numeradas sobre los errores o correcciones. De esta manera y exponiéndolas a modo de cuadro o presentación escrita, los alumnos no sólo podrán ver los comentarios a sus exámenes sino también los comentarios de los otros. Siguiente el desarrollo argumental de Coraggio, esta metodología permite desplazar la 
evaluación de la relación vertical docente/alumnos hacia una evaluación horizontal al establecer una comparación de la propia respuesta frente a la de los pares. Según el autor mencionado, algo importante para el docente, a la hora de evaluar es tener en cuenta que no siempre hay correspondencia entre el conocimiento interiorizado y la capacidad para expresarlo adecuadamente y que esta capacidad se desarrolla adicionalmente cuando el alumno ve otras formas de expresión de sus pares antes que cuando vuelve a recibir la forma canónica que ya estaba en el texto o en la exposición del docente.

En relación a los criterios y valoraciones que se recomiendan tener en cuenta a la hora de evaluar los cortometrajes, las producciones finales de los alumnos, resulta pertinente tener en cuenta que si bien se dicta un solo curso y contenido para todos, las comprensiones son distintas, cada alumno coproduce su propio sentido ante el mismo estímulo del docente. Para esta instancia de evaluación se recomienda tener en cuenta, recurrir a clases de apoyo en pequeños grupos o incluso individuales. Este recurso permite de alguna manera ajustar el sentido sobre algún contenido, de manera más personalizada, no siempre posible en una clase colectiva. Resulta muy importante ir propiciando y monitoreando el desarrollo de capacidades muy diversas de los alumnos. Si al comienzo del curso se dieron indicaciones muy precisas sobre las lecturas de los textos teóricos, a medida que se va avanzando con el curso, esa rigidez en el acercamiento propuesto al tema puede ir aflojándose para que los propios alumnos busquen por su cuenta aquello que resulta pertinente para el desarrollo de sus trabajos audiovisuales.

En relación a la evaluación final de los cortometrajes, se recomienda planificar las exposiciones de los mismos, de tal manera que se organice un debate reflexivo sobre la producción del grupo una vez finalizada la exposición.

Para finalizar con el proceso de evaluación se recomienda como pertinente trabajar con una herramienta de monitoreo del proceso de aprendizaje como resulta ser la encuesta final al alumno. En la misma el docente podrá encontrarse con las expectativas que los alumnos tenían sobre le curso y cómo se desarrollaron efectivamente durante la curso, si se generaron nuevas inquietudes como también si el aprendizaje finalmente resultó significativo.

\section{Conclusión}

El presente trabajo de exploración de la agenda profesional tiene un doble objetivo, por un lado la meta de cubrir necesidades en torno al poco material publicado y editado en el país sobre una tendencia en pleno crecimiento dentro del mundo audiovisual como ser la práctica del Found Footage, y como segundo objetivo generar a futuro la necesidad de incluir el presente trabajo en áreas de vacancia en ciertos programas académicos desactualizados que dejan por fuera una práctica tan trascendente como la nombrada anteriormente.

Como se mencionó al comienzo de dicho trabajo, las carreras y áreas que podrían resultar interesadas en la temática del Found Footage son aquellas vinculadas con el universo audiovisual: Licenciatura en Comunicación Audiovisual, Dirección Cinematográfica, Diseño de Imagen y Sonido en particular pero también tiene por objetivo ser material de consulta y fuente de referencia en carreras vinculadas a la imagen y al diseño en general. Una recomendación a tener en cuenta para lograr incorporar la presente temática a las planificaciones académicas de algunas materias de las carreras mencionadas previamente, es la de generar espacios de debate y reflexión entre docentes titulares de las materias pertinentes. Partiendo de la necesidad de una revisión de los contenidos generales de las asignaturas con una perspectiva que motive la actualización de los contenidos de las mismas. Se debería plantear en asignaturas a las que resulte pertinente una práctica como la del Found Footage, la 
lectura del presente trabajo como posible disparador y motivador para los docentes involucrados, para el estudio y la investigación de los materiales teóricos y audiovisuales pertenecientes a la temática. Es así como de este modo los docentes podrán valorar esta tendencia estética dentro del mundo de la imagen contemporánea como algo que va más allá de una moda sino que implica un replanteo de valores y conceptos aun vigentes, en el campo del arte actual.

Una vez alcanzado dicho nivel de conocimiento por parte de los docentes, podrá ser posible el desarrollo de la actividad propuesta en el presente trabajo: El objetivo de la propuesta de trabajo será la de desarrollar un trabajo de apropiación de un conocimiento teórico como ser el de la historia y características principales de la práctica del Found Footage a partir de la realización de un trabajo práctico que consista en la realización de un cortometraje realizado con los principios básicos de la práctica del Found Footage: reunión de material preexistente y de autoría no propia, y la postproducción que reúne ese material seleccionado a partir de una idea o concepto propio y diferente al original.

Una vez aprobado el presente trabajo podrá ser evaluado en relación a los logros alcanzados a través de las consignas propuestas en el mismo. Momentáneamente se recomienda a aquellos docentes interesados en incorporar la temática en alguna asignatura como a aquellos que también deciden incorporar como herramienta de evaluación el trabajo práctico aquí planteado, que visualicen cada material la cantidad de veces que sea necesario hasta comprenderlo lo suficientemente bien como para trabajar los diferentes conceptos que involucra dicha práctica, en diferentes clases y momentos: aura, postmodernidad, archivo, remix, etc. Es así, como también se recomienda una lectura exhaustiva del marco teórico aquí mencionado que a su vez abrirá el camino para investigar y estudiar otros autores que trabajaron con la temática desarrollada.

El segundo objetivo o expectativa a cubrir está vinculada a la necesidad de realizar un aporte teórico a la práctica del Found Footage, que según varios autores dedicados al tema, continúa siendo una constante dentro del ámbito académico vinculado a la investigación del campo audiovisual contemporáneo.

Uno de los autores que plantea dicho problema es Antonio Weinrichter en Metraje encontrado. La apropiación en el cine documental y experimental (2009, Navarra: Colección Punto de Vista). De acuerdo al autor esta práctica no ha recibido la debida atención hasta tal punto que llega a afirmar que la misma no ha existido como objeto teórico hasta la fecha reciente de publicación de su libro (2009). Resulta pertinente, que aquellos docentes que incorporen la presente temática en las planificaciones de las asignaturas adecuadas, tomen en cuenta ciertos conceptos desarrollados por Weinrichter. Sólo así podrán comprender las características de la esencia de la práctica del Found Footage. Por ejemplo una diferenciación clave para comprender dicha práctica es la que realiza el autor mencionado en relación a la distancia entre apropiación y cita: en el cine contemporáneo es muy común encontrar películas que citan, homenajean, copian, rehacen y establecen variaciones o pastiches sobre elementos de películas anteriores. Comúnmente este fenómeno se lo observa como una de las características fundamentales de la postmodernidad. Sin embargo, cuando se investiga la práctica estudiada en el presente trabajo, se logra descubrir un tipo de cita muy distinto. Esta diferenciación se da porque la misma no alude a una imagen anterior sino que se apropia directamente de ella. Es aquí donde resulta pertinente retomar los conceptos planteados anteriormente en torno a un cine que no puede definírselo desde un género sino desde una práctica o acción que tiene que ver con la apropiación de materiales preexistentes para generar con los mismos un nuevo discurso. 
En relación a estos conceptos descritos se puede vislumbrar la amplitud de intereses que puede abarcar esta temática. De hecho en materias o carreras que no estén estrechamente relacionadas con el mundo audiovisual como por ejemplo el caso de asignaturas que traten la problemática de los derechos de autor, también podrían tomar a la práctica del Found Footage como un caso a analizar. Esto se debe a una situación que está en la base de toda esta práctica que el autor Weinrichter lo analiza como aquellos problemas que esta práctica lleva implícito en su esencia. Todo esto como consecuencia de lo que implica trabajar manipulando materiales ajenos que indefectiblemente lleva a una serie de consecuencias esenciales. Por ejemplo, el artista no crea con los medios dramáticos del cine sino que impone su visión a materiales rodados por otros, es así como tergiversa la visión que éstos le habían querido dar a su material. Por otro lado, como ya se desarrolló previamente, la idea convencional de originalidad se olvida.

Volviendo a las sugerencias y recomendaciones para los docentes de carreras y asignaturas vinculadas al campo audiovisual, es sumamente importante incorporar dicha temática en aquellas asignaturas que trabajen con el montaje cinematográfico. En la práctica del Found Footage el montaje pasa a ocupar un lugar de preeminencia como elemento expresivo, creador de sentido. Es así como según el autor citado, el término con el que se denomina a esta práctica debería indicar que el trabajo comienza en la mesa de montaje a partir de planos existentes previamente. Este término debe indicar también que el film que se utiliza procede de algún momento pasado. Algo que es importante en el momento de analizar el nombre que se le da a esta práctica Found Footage es que resulta muy claro a la hora de expresar que el material con el que se trabaja en la mesa de montaje es un material ajeno arrancado de su contexto, es precisamente esa noción de apropiación que subyace en el término encontrado. Resulta pertinente, para aquellos docentes de montaje o de asignaturas que trabajen a partir del montaje cinematográfico, que tengan en consideración las diferentes etapas que implica esta práctica de apropiación de material ajeno: el acto propiamente de apropiación, el trabajo de ensamblaje o remontaje de los fragmentos, y el subsiguiente efecto de recontextualización o creación de un nuevo sentido. En este punto debe tenerse en cuenta también los procesos de recepción de dicho material. El espectador debe poseer un "alto grado de reconocimiento de las imágenes que se le presentan, su distancia sobre el material original y su reacción al mismo, pero también su grado de percepción del proceso de creación de sentido nuevo que ha tenido lugar" (Weinrichter, 2009).

Como se viene desarrollando a lo largo del presente trabajo de exploración profesional, esta práctica del Found Footage es lo suficientemente compleja como para abarcar diferentes áreas de conocimiento y de desarrollo profesional. Por ejemplo, algo que los docentes vinculados a asignaturas audiovisuales y de la imagen en general, sería conveniente que conozcan es que esta práctica no se encuentra limitada a ámbitos de experimentación o circuitos reducidos de exhibición sino que también este reciclaje de imágenes se presenta desde hace años en el cine comercial. Por ejemplo en las vanguardias cinematográficas de los '60 como ser la Nouvelle Vague esta práctica fue muy habitual. Concretamente con el cineasta Godard se puede realizar junto a los alumnos un trabajo de análisis en torno a su filmografía ya que se afirma que ha pasado de ser el cineasta que más citas y alusiones incluía en sus películas a ser el que ha legitimado el fenómeno de la citación entendido como la inclusión directa de fragmentos de películas. De esta forma logra familiarizar con el concepto de apropiación a muchos que no se habían preocupado anteriormente por esta práctica. Otro de los casos notorios, contemporáneos a Godard, es el de Alain Resnais con su film Hiroshima Mon Amour (1959). En el mismo recurre a la mezcla de material de ficción y documental. Este recurso a la yuxtaposición de materiales heterogéneos desafiaba la linealidad del cine clásico y constituía una marca de control del narrador- 
ensamblador. Más allá de los artistas modernistas, esta citación de materiales preexistentes, se da también como signo de la posmodernidad en el cine comercial. Es por este motivo que resulta interesante estudiar dicha práctica en diversas asignaturas pero por sobre todo, desde distintos puntos de vista que permitan identificar el nivel de complejidad que implica la misma. Un director que utilizó este recurso fue Brian de Palma quien había establecido la costumbre de citar la escena de la ducha de Psycho (Hitchcock, 1960) en varias de sus pelí- culas de los años 70: Sisters (1973), Phantom of Paradise (1974) y Dressed to Kill (1980), entre otras. Otro aspecto interesante a tener en cuenta a la hora de analizar ciertas prácticas del cine comercial, en particular, el estadounidense clase B de los 70, como aquella basada en fines comerciales y no artísticos, como ser la de utilizar por ejemplo vistosos planos generales, costosos planos de incendios y "planos-comodín como aquél de un mismo indio o soldado que se caía una y otra vez del mismo caballo, insertados con descaro esperando que la repetición pasase desapercibida en el fragor de la batalla" (Weinrichter, 2009). Por lo tanto, este punto, resulta ser uno más de justificación en relación a la necesidad de abordar y de incluir a la práctica del Found Footage en los contenidos de las más variadas asignaturas vinculadas a la imagen.

A modo de cierre de las sugerencias o recomendaciones a aquellos docentes interesados en trabajar con la presente temática, resulta imprescindible relacionar dicha práctica con el género documental. En relación a este género, resulta necesario aclarar conceptualmente a los alumnos desde qué lugar se está hablando, y es allí en donde los docentes deben aclarar que se trata del cine documental que utiliza material de archivo y practica con él una operación de montaje. Es importante aclarar aquí que debe dejarse de lado aquellos reportajes o documentales históricos que se limitan a utilizar el archivo para ilustrar o legitimar un comentario expositivo o un discurso conducido por entrevistas. El motivo sobre el cual se deja de lado a este tipo de documentales, es porque en ellos las imágenes de archivo se utilizan sin interrogar el sentido de las mismas, sino que por el contrario se propone al espectador una lectura lineal de las mismas, sin aquella actitud crítica y reflexiva que presupone la práctica del Found Footage. Este punto es interesante de plantear a los alumnos, ya que la compilación de imágenes es algo que forma parte de la tradición histórica del documental. Algo importante a rescatar en el tratamiento de por ejemplo, la historia del cine documental, es el papel que jugaron los noticiarios cinematográficos en las guerras mundiales. Por le valor propagandístico que promovieron es que puede identificarse muchos ejemplos de uno de los principios básicos que luego regirán en el cine de compilación: la reutilización combinatoria de un mismo material en diferentes contextos, con diferentes sesgo y énfasis para propiciar una lectura distinta. Es así como se establece que uno de los principios básicos del cine de archivo es que todo material es reutilizable, haciendo girar su lectura ideológica por ejemplo de un extremo a otro de acuerdo a la ubicación, duración y combinación de imágenes elegidas. El teórico Georges Sadoul comenta, sobre este tema, que a partir de los materiales tomados de las actualidades filmadas se puede "no sólo introducir cualquier tema, sino también demostrar cualquier tesis política, revolucionaria pero también contrarrevolucionaria" (1956).

Resulta indudable la vinculación de la práctica aquí analizada con el cine soviético de la década del '20. Escuela vanguardista que parte de una definición de montaje como un agente de tráfico que ordena y controla los significados de los planos haciéndolos ocupar un lugar en un encadenamiento metonímico. Es así como la cadena se rompe al sacar una imagen de ese contexto y el sentido de la imagen queda liberado hasta ocupar su lugar en una nueva cadena.

Para concluir este punto, sobre la importancia de incursionar didácticamente en esta temática, a la hora de tratar el abordaje del cine documental ya sea en su aspecto teórico como práctico, resulta necesario recalcar aspectos 
del marco teórico para abordarlo. En el cine documental el recurso al archivo tiende a tener el mismo sentido que las secuencias collage en un relato de ficción que sirven para proporcionarle un contexto. Lo que se buscar generar es un efecto de verosimilitud para lograr una legitimación histórica de la ficción o de la no ficción. En cambio en el compilation film el archivo no se utiliza para legitimar sino para producir un efecto persuasivo o retórico. De aquí surge aquello que permite resaltar la necesidad de continuar investigando y trabajando sobre la práctica del Found Footage y es que el archivo no se usa sólo para revisar la historia, sino que por el contrario sirve para revisar la representación de la historia y es a través de una deconstrucción histórica del cine documental que se realiza sólo con esta práctica. Por ende, es posible hablar de cómo algunas piezas pueden ser desmontadas, como aquellas de propaganda política y de todo tipo de viejos documentales, noticieros expositivos y actualmente el nuevo repertorio de programas televisivos, para poner en evidencia un efecto discursivo arbitrario y autoritario. Se trata de una tendencia en crecimiento, un nuevo tipo de cine de no ficción que propone una reflexión sobre un formato anterior.

Como se afirmó al comienzo de esta conclusión la mayoría de las expectativas han sido cubiertas. A futuro podrá evaluarse si efectivamente el presente trabajo se convierte en fuente de consulta como en material de estudio para los profesionales que deseen vincularse a esta práctica experimental de la creación audiovisual. Si bien el material, tanto teórico como audiovisual, resultó bastante complicado de conseguir y acceder al mismo, gracias al trabajo arduo de investigación y a la buena predisposición de ciertos artistas locales, se ha logrado concretar el objetivo de ofrecer una recopilación de contenidos y desglosa una serie de creadores audiovisuales pocas veces incluidos en las planificaciones académicas de las carreras nombradas.

Como objetivo también a evaluar a futuro, correrá por cuenta de aquellos docentes interesados en incorporar dicha temática, por los motivos anteriormente detallados. Sólo ellos y a través de la evaluación de un proceso de aprendizaje se podrá analizar las herramientas incorporados por los alumnos en torno a la ejercitación de una postura crítica y reflexiva frente al propio medio.

\section{Bibliografía}

Arthur, P. (2008). En busca de los archivos perdidos. En Archivos de la filmoteca 58. Valencia: Ediciones de la Filmoteca.

Bonet, E. (1993). Desmontaje: film, video/apropiación, reciclaje, Valencia: IVAM.

Bordieu, P. (1990). Campo intelectual y proyecto creador. En Sociología y cultura. México: Ed. Grijalbo.

Bourriaud, N. (2002). Estética Relacional, París: Presses du réel.

(2006). Postproducción, Bs. As., Adriana Hidalgo.

Galindo Cáceres, J. (1998). Técnicas de investigación en sociedad, cultura y comunicación. México: CNCA y Addison Wesley.

Hausheer, S. (1992). Found Footage Film, Luzern: VIPER.

Manovich, L. (2006). El lenguaje de los nuevos medios de comunicación. Bs. As.: Paidós. 
Sadoul, G. (1956). Historia del cine. Bs. As.: Losange.

Schön, D (1992). La enseñanza del arte a través de la reflexión en la acción. En Schön La formación de profesionales reflexivos. Hacia el diseño de la enseñanza y el aprendizaje de las profesiones. Bs. As.: Paidós.

Trerotola, L. (Comp.) (2010). Cine encontrado: ¿Qué es y adónde va el found footage? Bs. As.: BAFICI.

VV.AA. (1998). Propuestas al margen: falso documental y metraje encontrado. En Archivos de la filmoteca, Valencia: Paidós.

Wees, W. (1993). Recycled Images: The Art and Politics of Found Footage Films, Nueva York: Anthology Film Archives.

Weinrichter, A. (2009). Metraje encontrado. La apropiación en el cine documental y experimental. Navarra: Colección Punto de Vista.

Young P. y Duncan P. (Ed) (2009). Cine artístico. Colonia: Taschen.

Zabalza, M. A. (2010, enero-junio). El trabajo por competencias y los equipos docentes. Ventanas abiertas a la pedagogía universitaria. Cuaderno de Pedagogía Universitaria, 7 (13), 5-13.

\section{Recursos electrónicos}

Brenez, N. Cartographie du found footage, disponible en: www.archives.arte.tv Coraggio, J. L. (2004) Qué aprendí enseñando Economía? Documento descargado de Biblioteca Digital. www.educ.ar Jacobsen, U. En busca del sentido perdido. En torno al found footage, revista electrónica Fuera de campo: http://www.fueradecampo.cl/Articulos/foundfootage.html Wees, W. Found Footage y el aura ambigua de Hollywood, Cinema Journal, Vol. 41, No. 2 (2002), trad. Disponible en www.visionesmetaforicas.blogspot.com

2.1. El Found Footage como práctica del video-arte argentino de la última década fue publicado de la página 176 a página202 en Cuadernos del Centro de Estudios de Diseño y Comunicación № 63 